Elsevier

\title{
Rapid communication
}

\section{HIGH CORRELATION BETWEEN THE LOCALIZATION OF $\left[{ }^{3} H \mid T C P\right.$ BINDING AND NMDA RECEPTORS}

\author{
WILLIAM F. MARAGOS, DOROTHY C.M. CHU, J. TIMOTHY GREENAMYRE, JOHN B. PENNEY and \\ ANNE B. YOUNG *
}

Department of Neurology and the Neuroscience Program, University of Michigan, Ann Arbor, MI 48109, U.S.A.

Tritiated N-(1-[2-thienylcyclohexyl)-3,4-piperidine $\left(\left[{ }^{3} \mathrm{H}\right] \mathrm{TCP}\right)$, a derivative of the dissociative anesthetic phencyclidine (PCP), has recently been shown to bind specifically to a $\sigma$-opiate receptor within the central nervous system of the rat (Sircar and Zukin, 1985). Drugs of this class noncompetitively inhibit the excitatory properties of $\mathrm{N}$ methyl-D-aspartate (NMDA), a glutamate analogue, in the spinal cord (Martin and Lodge, 1985), and inhibit long-term potentiation in the hippocampus (Stringer et al., 1983). Both of these effects are thought to be mediated by NMDA-sensitive glutamate receptors. The NMDA receptor is coupled to a voltage-sensitive cation channel that is gated by $\mathrm{Mg}^{2+}$. It is at this channel site that PCP and related compounds are believed to act. In order to further delineate the relationship between the dissociative anesthetics and NMDA receptors, we have compared the regional binding distribution of the $\sigma$-specific compound $\left[{ }^{3} \mathrm{H}\right] \mathrm{TCP}$ and NMDA-sensitive $\left[{ }^{3} \mathrm{H}\right.$ ]glutamate binding sites within the rat $\mathrm{CNS}$ using quantitative autoradiography.

Radiolabelling of each receptor class was carried out on alternate $20 \mu \mathrm{m}$ thick slide mounted sections taken at various levels of rat forebrain. For $\left[{ }^{3} \mathrm{H}\right] \mathrm{TCP}$ binding, sections were preincubated for $30 \mathrm{~min}$ in cold $50 \mathrm{mM}$ Tris-acetate, $\mathrm{pH} 7.4$ and then dried. Sections were then incubated for 45 min in the same buffer with $1 \mathrm{mM}$ magnesium acetate and $20 \mathrm{nM}\left[{ }^{3} \mathrm{H}\right] \mathrm{TCP}(52.9 \mathrm{Ci} / \mathrm{mmol}$, New England Nuclear Corp.) in the presence or ab-

\footnotetext{
* To whom all correspondence should be addressed: Neuroscience Laboratory Building, 1103 East Huron Street, Ann Arbor, MI 48104, U.S.A.
}

sence of $20 \mu \mathrm{M}$ PCP. Sections were then washed three times, one minute each, in cold buffer with $\mathrm{Mg}^{2+}$ and rapidly dried. $\left[{ }^{3} \mathrm{H}\right]$ Glutamate binding was carried out under conditions that have been shown to select for NMDA receptors (Greenamyre et al., 1985a). Briefly, sections were preincubated for $30 \mathrm{~min}$ in cold $50 \mathrm{mM}$ Tris-acetate, $\mathrm{pH} 7.4$, and dried. Sections were then incubated in the same buffer with $200 \mathrm{nM} \mathrm{L-}\left[{ }^{3} \mathrm{H}\right]$ glutamate (39 $\mathrm{Ci} / \mathrm{mmol}$, Amersham Corp.). Sections were rapidly washed three times with three $\mathrm{ml}$ of cold buffer, followed by one rinse with a mixture of cold glutaraldehyde and acetone $(1: 19 \mathrm{v} / \mathrm{v})$ and then rapidly dried. Autoradiograms were generated and analyzed as previously described (Greenamyre et al., 1985a).

A striking similarity was observed between the relative densities of $\left[{ }^{3} \mathrm{H}\right] \mathrm{TCP}$ and NMDA receptor binding in all eight regions studied (fig. 1). Bound values in $\mathrm{pmol} / \mathrm{mg}$ protein were determined densitometrically for both ligands in eight regions from each of four brains. The values for the two ligands were highly correlated (Pearson's $\mathrm{r}=0.95 ; \mathrm{P}<0.001$ ). Highest densities were observed in stratum radiatum of $\mathrm{CA} 1$ field in hippocampus for both ligands (NMDA $=19.0 \pm$ $1.7 \mathrm{pmol} / \mathrm{mg}$ protein; TCP $=3.12 \pm 0.22 \mathrm{pmol} /$ $\mathrm{mg}$ protein). High levels of binding at both receptor sites were also observed in the dentate gyrus and stratum oriens of the CA1 region of hippocampus, layers 1 and 2 of somatosensory cortex, and the visual cortex. Moderate levels were observed in the striatum, thalamus, basolateral amygdala, deep layers of the cerebral cortex, medial geniculate and external plexiform layer of the olfactory bulbs. Very little binding was seen in the 

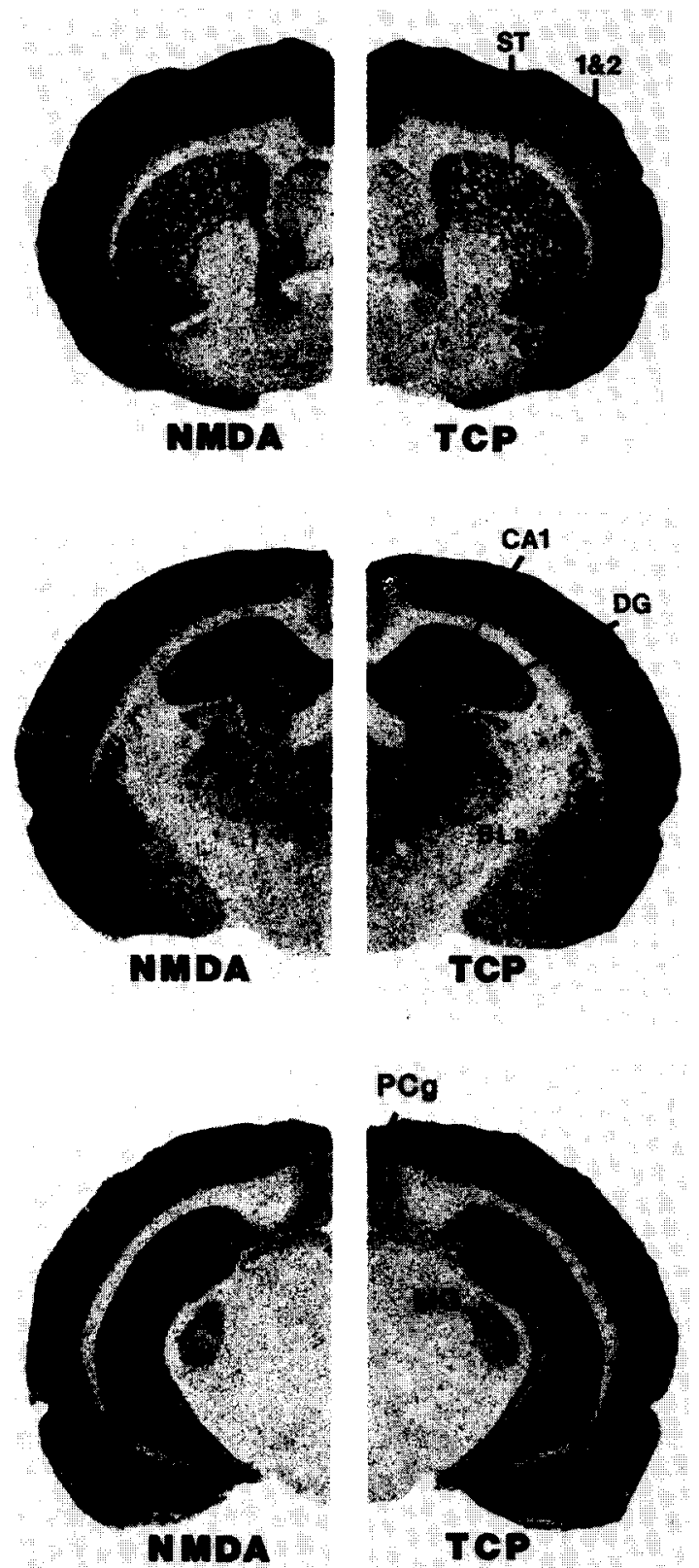

Fig. 1. Autoradiographic localization of $\left[{ }^{3} \mathrm{H}\right] \mathrm{TCP}$ binding (right) and $\left[{ }^{3} \mathrm{H}\right]$ glutamate binding to NMDA receptors (left) in telencephalon (top), diencephalon (middle) and mesencephalon (bottom) of rat brain. Serially adjacent sections were incubated in one of the two ligands. Autoradiograms were produced as described in the text. All sections are from the left hemisphere but the TCP autoradiograms were reversed before printing. Abbreviations are: BLa, basolateral amygdala; CA1, CA1 region of hippocampus; DG, dentate gyrus; MG, medial geniculate; $\mathrm{PCg}$, posterior cingulate gyrus; $\mathrm{ST}$, striatum; 1 \& 2, layers 1 and 2 of somatosensory cortex. posterior cingulate gyrus and brainstem structures. Negligible binding was noted in white matter tracts.

We provide evidence for a marked concordance in the distribution of TCP and NMDA binding sites. While the correlation between the relative numbers of each of these binding sites was quite high, there was a 5 - to 10 -fold greater number of NMDA than TCP sites. This disparity suggests that either TCP binds to a subset of NMDA receptor channels or that more than one molecule of NMDA binds to each receptor-channel complex. Detailed saturation curves in all the various regions will be necessary to help answer this question. Our data provide direct autoradiographic evidence that regional localization of the so-called ' $\sigma$-opiate' binding site is highly correlated with the distribution of NMDA receptors. Since NMDA receptor pathology has been demonstrated in patients with Alzheimer's disease (Greenamyre et al., $1985 b$ ), radiolabeled TCP may prove to be a useful probe for studying NMDA receptors in man with positron emission tomography (PET).

\section{Acknowledgements}

Supported by the A.C. and Ersa Arbogast foundation, USPHS grants NS 15655, NS 19613 and NIMH Individual Predoctoral NRSA 1 F31 MH08922 to JTG. We thank Dr. E. Domino for kindly supplying us with PCP. We thank Jan Pappas for secretarial assistance.

\section{References}

Greenamyre, J.T., J.M.M. Olson, J.B. Penney and A.B. Young, 1985a, Autoradiographic characterization of N-methyl-Daspartate-, quisqualate- and kainate-sensitive glutamate binding sites, J. Pharmacol. Exp. Ther. 233, 254.

Greenamyre, J.T., J.B. Penney, A.B. Young, C.J. D'Amato, S.P. Hicks and I. Shoulson, 1985b, Alterations in L-glutamate binding in Alzheimer's and Huntington's diseases, Science 227, 1496.

Martin, D. and D. Lodge, 1985, Ketamine acts as a non-competitive $\mathrm{N}$-methyl-D-aspartate antagonist on frog spinal cord in vitro, Neuropharmacology 24, 999.

Sircar, R. and S.R. Zukin, 1985, Quantitative localization of $\left[{ }^{3} \mathrm{H}\right] \mathrm{TCP}$ binding in rat brain by light microscopy autoradiography, Brain Res. 344, 142.

Stringer, L.J., J.T. Hackett and P.G. Guyenet, 1984, Long-term potentiation blocked by phencyclidine and cyclazocine in vitro, European J. Pharmacol. 98, 381. 